Revue d'études américaines. American Studies Journal

$2 \mid 2017$

(Hi)stories of American Women: Writings and Rewritings / Call and Answer: Dialoguing the American West in France

\title{
Call and Answer: Dialoguing the American West in France
}

\author{
Emily C. Burns and Agathe Cabau
}

\section{OpenEdition}

\section{Journals}

\section{Electronic version}

URL: https://journals.openedition.org/transatlantica/10676

DOI: 10.4000/transatlantica.10676

ISSN: 1765-2766

Publisher

Association française d'Etudes Américaines (AFEA)

\section{Electronic reference}

Emily C. Burns and Agathe Cabau, "Call and Answer: Dialoguing the American West in France",

Transatlantica [Online], 2 | 2017, Online since 13 May 2019, connection on 02 February 2023. URL: http://journals.openedition.org/transatlantica/10676 ; DOI: https://doi.org/10.4000/transatlantica. 10676

This text was automatically generated on 2 February 2023.

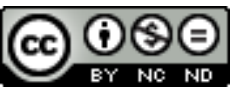

Creative Commons - Attribution-NonCommercial-NoDerivatives 4.0 International - CC BY-NC-ND 4.0 https://creativecommons.org/licenses/by-nc-nd/4.0/ 


\title{
Call and Answer: Dialoguing the American West in France
}

\author{
Emily C. Burns and Agathe Cabau
}

This special issue is dedicated to the memory of François Brunet, with gratitude for his broad conceptual intellect, incisive questioning, vigorous archival research, and generous mentoring of junior scholars. Conversations on Franco-U.S. exchange ahead will be less rich and lively without his provocative and productive interventions.Emily \& Agathe

1 Ideas of the American West have often been at the fulcrum of Franco-U.S. cultural exchange. Uttering the phrase "the American West" in France likely conjures not a single image, but a panoply of representations. Even today, French people recall stereotypes built by Tintin en Amérique, and cartoons like Blueberry and Lucky Luke. Wooden sculptures of cigar store Indians are not uncommon outside of boutiques or restaurants in small French cities, such as Dakota Café in Tours. One of the bouquinistes along the Seine sells only French-language novels and books related to the American West. The West's continued imaginary appeal is also suggested by the success of the Paris restaurant chain Indiana Café, which sports a profile image of an American Indian wearing a war bonnet for its logo. The interiors are decorated with ethnographic photographs of American Indians from the nineteenth and early twentieth centuries by Edward Curtis, William Henry Jackson and other photographers. The site features a mostly Tex-Mex menu "[à la] frontière entre restaurant américain et mexicain." The cohesion of Tex-Mex food, Plains Indians, Indiana, and Mexico elide significant cultural differences, yet such amalgamations have a long history in how the American West has figured in France, the focus of this special issue of Transatlantica.

2 Representations that imagined and constructed western life, landscape, and people have long circulated in France in literature and art. These images were never documents, but rather were always targeted to meet social and cultural needs on both sides of the Atlantic. Imagery depicting the American West circulated widely: in high art venues like the Paris Salons and Universal Expositions (Cabau; Salomé; Burns) and 
in popular spectacle, such as in Buffalo Bill's Wild West and other public venues like the Jardin d'Acclimatation, as well as in posters and mass media (Burns; Bleton; Villerbu; Voelker). The range of imagery and contexts suggests a blending of popular culture and fine art contexts that challenges institutional hierarchies between high and low often enforced by the academy. These essays reveal and investigate the discursive overlaps across those boundaries. Furthermore, spaces of negotiation and contestation can be found in both popular and fine art media; they appear both in the complication of presumptions of Native Americans' primitive identities beyond the performance space (Voelker; Horton; Burns), and in the penchant for U.S. artists to exhibit in the Paris Salon representations of Native American dance that were then forbidden by assimilationist policies in the US. ${ }^{1}$ The malleability and foreignness of icons like the cowboy, the American Indian, the trapper, and even the Mormon, enabled the West to be adopted and adapted within French political and social discourses. Yet such representations were not freeform; many U.S. and Native American figures participated in shaping these adaptations and projecting their own experiences and constructions of the West onto French culture. How did France not only absorb and adopt their own constructions of the West but also refract U.S. imaginations?

Figure 1

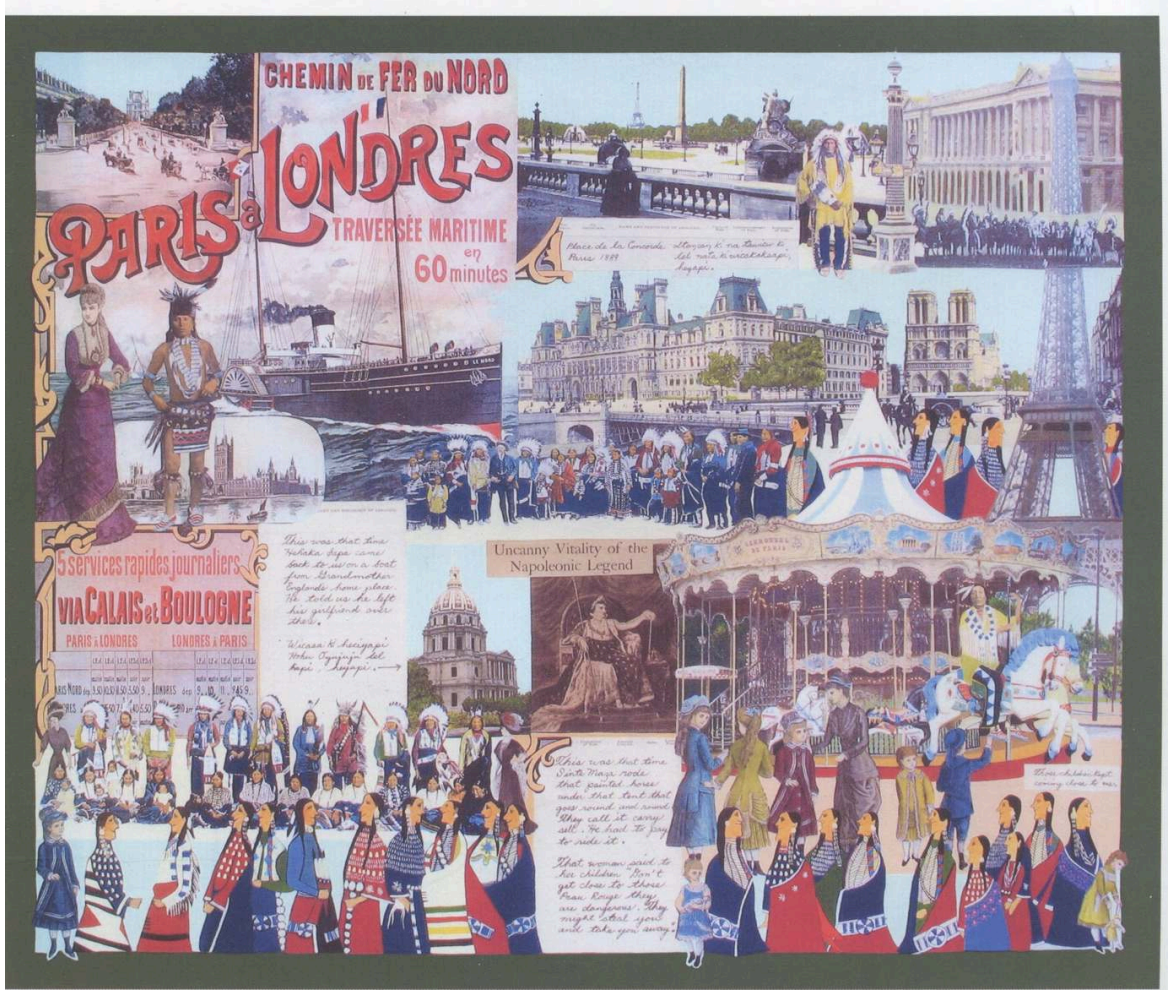

Arthur Amiotte, In France 1889, 2007, collage, 30 × 36", Collection of Raymond DeMallie, Bloomington, IN

Contemporary Oglala Lakota artist Arthur Amiotte has produced a series of collages related to Lakota explorations in Europe that speak to the transnational and transcultural issues raised by the essays in this volume. During a Monet Foundation artists' residency fellowship in Giverny in 1997, Amiotte searched for fin-de-siècle visual materials at the bouquinistes along the Seine, imagining himself following in the footsteps of the Lakota performers, including his grandfather, Mathó Nážiy (Standing 
Bear), who was a performer in Paris in 1889. In France 1889 (Figure 1) couples photographs of Wild West performers alongside collaged photographs of Europeans, with painted figures drawn from Kiowa ledger books from the 1870s (Berlo 9), and with fin-de-siècle posters and photographs from a Paris 1900 calendar (Amiotte). Amiotte highlights the experiences of Buffalo Bill's Wild West performers' tourism in Paris, making stops at the Hotel de Ville, Notre Dame, the Champs Élysées, the Place de la Concorde, the carousel and the Eiffel Tower, which they appear to ascend. ${ }^{2}$ Reminding that the performers were spectators as well as the objects of the gaze, Amiotte includes clippings of ledger books with handwritten Lakota phrases that comment on the imagined perceptions of the foreign locale by the performers, noting, for instance the beheadings at the Place de la Concorde. The performers visit Napoléon's tomb at les Invalides, where a ledger note makes a pun in Lakota about the emperor as "Wičáša Ki hečíyapi Hohú Oyúžužu lél hapi, heyapi." ("The man whose bones are all apart. He is buried here.") ${ }^{3}$ (Amiotte) while the newspaper announces Napoléon's "uncanny vitality." In the process of drawing on Euro-American and Plains Indian visual practices, Amiotte underscores both Paris and the Plains as sites for Lakota cosmopolitanism. For Amiotte, as for all of the authors in this special issue, the American West is a circulating and mobile construct, adapted and continually renegotiated and re-defined, as unfixed, contested and porous as the borderlands themselves in the nineteenth century.

4 This research contributes to larger conversations about the relationships between culture and the politics of mobility, identity, geography, and modernity. It builds on recent discussions of circulation and the dialectics between mobility and immobility (Brunet; Harney and Phillips; Huyssen; Weaver). The objects and people involved in these interactions and transactions can be understood as an example of what French scholars Michael Werner and Bénédicte Zimmerman have called "histoire croisée," or crossed history, as they overlap on key questions of land, terrain, identity, modernity, and Native rights. The visual culture of the American West in France offers a unique point of entry into cultural questions such as the relationship between cosmopolitanism and provincialism in French and U.S. cultures, how regional identities are defined, the role of cultural nationalism in the production of images, modernist primitivism, colonial power relationships, and the dynamics of transnational artistic production. In triangulated relationships between French, non-Native American, and American Indian actors, one finds narratives of appropriation and subjugation, but also spaces for transculturation and autoethnography. The essays reveal the multiplicity of constructions of the West in various formats, and even within each, uncover multilayered and inconsistent constructions.

This special issue collects eight essays that analyze multiple constituencies in transnational exchanges that centered around ideas of the West. Four authors examine French writers and artists who experimented with and exploited the pliability of western imagery, including Gustave Aimard, Gustave Courbet, Albert Robida, and Paul Gauguin. Luca DiGregorio analyzes the construction of the mountain man, or "coureur de bois" in early-to-mid-nineteenth-century French literature, focusing on the writings of Aimard to explore the function of this fictionalized figure. Jane Mayo Roos explores the interwoven histories of George Catlin's display of Iowa and Ojibwe performers in Paris in the 1840s and George Sand's critique of settler colonialism, speculating on the possible manifestations of the performers in some of the figures in Courbet's The 
Painter's Studio: A Real Allegory Summing up Seven Years of my Artistic and Moral Life (1855; Musée d'Orsay). Roos considers how these figures might reveal a critique of U.S. treatment of Native American communities, and, in concert with the child drawing on the floor towards the right of the painting, argues that Catlin's paintings of American Indians also informed the construction of French modernism. Daryl Lee turns to literature and visual culture with his analysis of Albert Robida's constructions of Mormons in the 1870s and 1880s in text and illustration. He argues that Robida's imagined and caricatured Mormons are wrapped up with French gender politics, female emancipation, and colonialist discourse. Also addressing gender discourses, Nancy Mowll Mathews takes more seriously Gauguin's sporting of a cowboy hat in Tahiti as a point of entry into his exoticized self-fashioning, his attempts to construct his ancestry in the Americas, and in re-thinking his modernist practice. In the process, she tackles both the masculinities and gender non-normativity furthered by Buffalo Bill's Wild West in France. Her essay highlights the circulation of Western constructs far afield from even French terrain as they shaped parts of Gauguin's Tahitian persona. All of these essays reveal the adaptability of the western motif and metaphor in nineteenth-century French society.

6 Additionally, four essays analyze U.S. projections of the West into the French social and performance space. François Brunet and Jessica Talley investigate U.S. displays of Western resources at the 1867 Universal Exposition, and California and Colorado in particular as sites that foregrounded technologies and untapped natural resources. In the process, the U.S. display built a narrative of U.S. boosterism around a "new aesthetics of the West." Such boosterism was reinforced in the 1890s, as James Swenson argues, by U.S. artists from the West who used their biography to shape their intersections with the French artworld in the 1890s. These artists built up frontier life in their art, but also played with the idea of Paris as a metaphorical frontier.

7 While Roos focuses on the struggles of American Indian performers in France in the 1840s, subsequent essays underscore the savvy and complex identity constructions engaged by American Indians in Paris, for whom Paris became a space of possibility rather than restriction. Indeed, Native Americans also shaped the discourses of the West in France, as Emily Voelker and Jessica Horton both explore in their analyses. These authors ask, what are the spaces of possibility for American Indian identity and modernity to be asserted in France? Voelker considers how the agency of $U m o^{n} h o^{n}$ performers at the Jardin d'Acclimatation in 1883 resonates within Roland Bonaparte's ethnographic photographs of them, both through self-fashioning and through the mobility of the albums, which were often sent to the United States. These images complicate and push the bounds of identity inscribed by restrictive modes of anthropology. Picking up in the 1930s, Horton highlights the challenges to projections of Indianness through visual play, made both by Santa Fe Indian School artists who sent painted posters at the request of Indianist Paul Coze to advertise a Native American art exhibition at the Musée d'Ethnographie de Trocadero and by Native American performers like Molly Spotted Elk who traveled to Paris. This essay explores the potential of online publishing with audio-files and a gallery of all of the known posters advertising the 1935 exhibition.

8 Four of the essays in this special issue originated in presentations at "The American West: A French Appropriation," hosted at the Institut National d'histoire de l'art in March 2015. These study days were generously supported by the Institut national 
d'histoire de l'art in partnership with the research groups LARCA (Laboratoire de recherches sur les cultures Anglophones UMR 8225, Université Paris Diderot), HAR (Histoire des arts et représentations EA 4414, Université Paris-Ouest Nanterre la Défense), InTRu (Interactions, transferts, ruptures artistiques et culturels EA 6301, Université François-Rabelais de Tours), and the Terra Foundation for American Art, with additional support from Institut Universitaire de France (IUF). The additional four essays have been commissioned from the editors.

\section{BIBLIOGRAPHY}

AMIOTTE, Arthur. Interview with Emily C. Burns, Custer, SD, September 13, 2018.

BERLO, Janet C. Arthur Amiotte Collages 1988-2006. Santa Fe : Wheelwright Museum of the American Indian, 2006.

BLETON, Paul. Western, France : La Place de l'Ouest dans l'imaginaire français. Amiens : Encrage/Les Belles Lettres, « Travaux », 2002.

BRUNET, François, ed. Circulation. Chicago : Terra Foundation for American Art, 2017.

BURNS, Emily C. Transnational Frontiers : the American West in France. Norman : University of Oklahoma Press, 2018.

CABAU, Agathe. "L'iconographie amérindienne aux Salons parisiens et aux Expositions universelles françaises (1781-1914).” Ph.D. diss., Université Paris 1 Panthéon Sorbonne, 2014.

HARNEY, Elizabeth and Ruth B. Phillips. Mapping Modernisms : Art, Indigeneity, Colonialism. Durham : Duke University Press, 2019.

HORTON, Jessica L. Art for an Undivided Earth : The American Indian Movement Generation. Durham : Duke University Press, 2017.

HUYSSEN, Andreas. "Geographies of Modernism in a Globalizing World." Geographies of Modernism : Literatures, Cultures, Spaces. Eds. Peter Brooker and Andreas Huyssen. London : Routledge, 2005, p. 6-18.

PORTES, Jacques. Une fascination réticente. Les États-Unis dans l'opinion française. Nancy : Presses universitaires de Nancy, 1990.

LAKOTA LANGUAGE CONSORTIUM. New Lakota Dictionary. 2nd ed. Bloomington : Lakota Language Constortium, 2016.

SALOMÉ, Laurent. La Mythologie de l'ouest dans l'art américain 1830-1940. Milan : Silvana Editoriale, 2007.

VILLERBU, Tangi. La Conquête de l'Ouest, Le récit français de la nation américaine au xixe siècle. Rennes : Presses universitaires de Rennes, 2007.

VOELKER, Emily L. "From Both Sides of the Lens: Anthropology, Native Experience and Photographs of American Indians in French Exhibitions, 1870-1890." Ph.D. diss., Boston University, 2017. 
WEAVER, Jace. The Red Atlantic: American Indigenes and the Making of the Modern World, 1000-1927. Chapel Hill: University of North Carolina Press, 2014.

WERNER, Michael and ZIMMERMAN, Bénédicte. "Penser l'histoire croisée : Entre empirie et réflexivité." Annales. Histoire, Sciences Sociales, vol. 58, no. 1, 2003, p. 7-36.

\section{NOTES}

1. Examples include Paul Wayland Barlett's Indian Dancer (Smithsonian American Art Museum); Solon Borglum's Sun Dance (unlocated); Herman Atkins MacNeill's Mocqui Prayer for Rain (Metropolitan Museum of Art), which were all shown in Paris exhibition spaces (Cabau).

2. Some of the performers did ascend the Eiffel Tower on August 9 and 13, 1889 (Burns 189, fn. 40).

3. We follow the diacritical markings from Lakota Language Consortium. 